\title{
The lichens of Glasgow Botanic Gardens
}

\author{
I.C. Wilkie \\ Institute of Biodiversity, Animal Health and Comparative Medicine, University of Glasgow, Glasgow G12 8QQ \\ E-mail: iain.wilkie@glasgow.ac.uk
}

\begin{abstract}
A total of 62 lichen taxa was found during a survey of Glasgow Botanic Gardens, Scotland conducted in 2018-20. This adds 54 taxa to the previous list of 14 recorded in the Gardens. Twelve lichen species have not been previously recorded in Glasgow and two Catillaria nigroclavata and Verrucaria dolosa - are new to VC77 (Lanarkshire). Factors affecting the distribution and diversity of lichens in the Gardens are discussed.
\end{abstract}

\section{INTRODUCTION}

Lichens are fungi that form a stable symbiotic relationship with algae or cyanobacteria ("blue-green algae"). They thrive on a huge range of both natural and man-made substrates from the Arctic and Antarctic to the tropics, and from the intertidal zone to an elevation of at least 7,400 $\mathrm{m}$ in the Nepalese Himalayas (Lutzoni \& Miadlikowska, 2009; Baniya et al., 2010). Whilst the vast majority of lichens are highly sensitive to air pollution of one form or another, the relatively few that are more tolerant ensure that lichens are rarely absent from city centres: even in the 1920s, around the time when Glasgow was at its industrial zenith, it was noted that lichens were present in all municipal wards of the city (Stewart, 1925).

There is very little published literature on the lichens of Glasgow. It appears that Stewart's paper cited above is the only one devoted exclusively to this component of the city's biota. Stewart found 11 species. The only other publication providing information on Glasgow's lichens is Elliot (1901), which gives the city as the location of 12 species, none of which was subsequently recorded by Stewart (1925). Other information on Glasgow lichens is contained in "grey" literature such as commissioned environmental surveys and student theses, but these tend to be poorly catalogued and difficult to access. The most up-to-date source of information on the distribution of British lichens is the British Lichen Society (BLS) Database, which currently gives Glasgow as a location of 158 lichen species (B.J. Coppins, pers. comm.).

The earliest record of lichens in Glasgow Botanic Gardens (GBG) is that of O'Hare (1974), who found only the crustose species Lecanora conizaeoides, which is highly tolerant of sulphur dioxide pollution and was then the commonest lichen in the city. The present author made brief visits to GBG in 1975 and 1986, recording a total of 14 species.
This paper describes the results of a survey of the lichens of GBG conducted in 2018-20, during which an additional 54 species were found.

\section{MATERIALS AND METHODS}

The Gardens were visited on seven occasions in 2018-20, the total time spent on the survey being ca. $15 \mathrm{~h}$. All types of potential lichen substrates were examined, i.e. the bark of trees (both in situ and as shed flakes); lignum (decorticated wood of park benches and the Ha'penny Bridge); stone (both dressed and undressed or natural surfaces); brick; man-made calcareous substrates (mortar and concrete); and asphalt paths.

Small samples of all crustose (crust-like) species and most foliose (leaf-like) and fruticose (bush-like) species were collected and identified in the laboratory. The identification of samples was based on standard chemical spot tests, examination of external features in a Leica Wild M32 stereomicroscope, examination of squash preparations of fungal fruiting bodies in an Olympus CX40 compound light microscope, and consultation of keys in Smith et al. (2009) and Dobson (2018). Squash preparations were preserved in lactophenol cotton blue. The identification of all critical material, including most crustose samples, was verified by Dr B.J. Coppins, who is the British Lichen Society Database Manager for Scotland. The nomenclature follows that of the Lichen Taxon Dictionary of the British Lichen Society

(https://www.britishlichensociety.org.uk/resources/lich en-taxon-database).

\section{RESULTS}

\section{General}

The main features of the lichen communities present on each type of substrate are described first and then an annotated list of the lichen taxa found in GBG is provided. The results are summarised in Table 1, which also indicates those species not previously recorded in NS56 (the $10 \mathrm{~km}$ square within which GBG is located), Glasgow or VC77 (Lanarkshire), according to the BLS Database (B.J. Coppins, pers. comm.). Information on previous records was obtained from the same database. 


\begin{tabular}{|c|c|c|c|c|c|c|c|c|c|c|c|c|c|c|c|c|c|c|c|c|c|}
\hline \multirow[b]{2}{*}{ Taxon name } & \multicolumn{17}{|c|}{ Substrate } & \multirow[b]{2}{*}{ 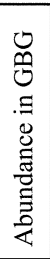 } & \multirow[b]{2}{*}{$\begin{array}{l}0 \\
2 \\
0 \\
z \\
0 \\
0 \\
3 \\
z \\
z\end{array}$} & \multirow[b]{2}{*}{$\begin{array}{l}3 \\
0 \\
80 \\
0 \\
0 \\
0 \\
0 \\
0 \\
3 \\
0 \\
z\end{array}$} & \multirow[b]{2}{*}{$\begin{array}{l}\hat{N} \\
0 \\
0 \\
0 \\
0 \\
0 \\
0\end{array}$} \\
\hline & $\frac{\overline{0}}{\frac{0}{4}}$ & $\frac{n}{2}$ & 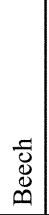 & $\stackrel{\frac{s}{0}}{0}$ & 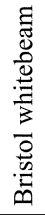 & 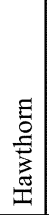 & 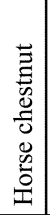 & $\begin{array}{l}0 \\
\frac{\pi}{2} \\
\tilde{2} \\
\tilde{0} \\
\tilde{0} \\
0\end{array}$ & 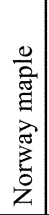 & 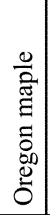 & $\Xi$ & 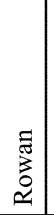 & 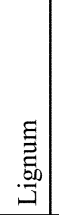 & $\begin{array}{c}\stackrel{\Xi}{0} \\
\stackrel{\tilde{D}}{\Delta}\end{array}$ & 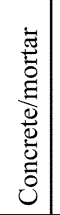 & 弟 & $\begin{array}{l}\frac{\pi}{\pi} \\
\frac{\pi}{2} \\
\frac{\pi}{4}\end{array}$ & & & & \\
\hline Anisomeridium polypori & & & & & & & & & & $\mathrm{x}$ & & & & & & & & $\mathrm{R}$ & & & \\
\hline Arthonia radiata & $\mathrm{X}$ & $x$ & & & & & & & $\mathrm{X}$ & & & $x$ & & & & & & $\mathrm{~F}$ & & & \\
\hline Baeomyces rufus & & & & & & & & & & & & & & $\mathrm{x}$ & & & & $\mathrm{R}$ & & & \\
\hline Caloplaca chlorina & & & & & & & & & & & & & & $\mathrm{x}$ & & & & $\mathrm{R}$ & $\mathrm{x}$ & $\mathrm{x}$ & \\
\hline Caloplaca citrina s. lat. & & & & & & & & & & & & & & $\mathrm{x}$ & $\mathrm{x}$ & & & $\mathrm{O}$ & & & \\
\hline Candelariella vitellina f. vitellina & & & & & & & & & & & & & & $\mathrm{X}$ & & & & $\mathrm{R}$ & & & \\
\hline Candelariella xanthostigmoides & & $\mathrm{x}$ & $\mathrm{X}$ & $\mathrm{x}$ & & & & $\mathrm{x}$ & $\mathrm{X}$ & & $\mathrm{x}$ & & $\mathrm{x}$ & & & & & $\mathrm{F}$ & & & \\
\hline Catillaria nigroclavata & & $x$ & & & & & & & & & & & & & & & & $\mathrm{R}$ & $\mathrm{x}$ & $\mathrm{x}$ & $x$ \\
\hline Cladonia chlorophaea s. lat. & $\mathrm{x}$ & & & & & & & & & & & & $\mathrm{x}$ & & & & & $\mathrm{R}$ & & & \\
\hline Cladonia coniocraea & & $\mathrm{x}$ & & & & & & & $\mathrm{x}$ & & & & & $\mathrm{x}$ & & & & $\mathrm{O}$ & & & \\
\hline Cladonia macilenta & & & & & & & & & $\mathrm{x}$ & & & & & & & & & $\mathrm{R}$ & & & \\
\hline Clauzadea monticola & & & & & & & & & & & & & & & $x$ & & & $\mathrm{R}$ & & & \\
\hline Evernia prunastri & $\mathrm{X}$ & & & & & & & & & & $\mathrm{x}$ & & & & & & & $\mathrm{O}$ & & & \\
\hline Flavoparmelia caperata & $\mathrm{x}$ & & & & & & & & & & & & & & & & & $\mathrm{O}$ & & & \\
\hline Fuscidea lightfootii & $\mathrm{X}$ & & & & & & & $x$ & & & & & & & & & & $\mathrm{O}$ & & & \\
\hline Graphis elegans & $\mathrm{x}$ & & & & & & & & & & & & & & & & & $\mathrm{R}$ & $\mathrm{x}$ & & \\
\hline Hypogymnia physodes & $\mathrm{x}$ & & & & & & & $x$ & & & $\mathrm{x}$ & & & & & & & $\mathrm{F}$ & & & \\
\hline Hypogymnia tubulosa & $\mathrm{x}$ & & & & & & & & & & & & & & & & & $\mathrm{O}$ & & & \\
\hline Lecania cyrtella & & & & & & & & & & & & $\mathrm{x}$ & & & & & & $\mathrm{R}$ & $\mathrm{x}$ & $\mathrm{x}$ & \\
\hline Lecanora campestris subsp. campestris & & & & & & & & & & & & & & $\mathrm{x}$ & & & & $\mathrm{O}$ & & & \\
\hline Lecanora carpinea & $\mathrm{x}$ & & & & & & & & & & & & & & & & & $\mathrm{R}$ & & & \\
\hline Lecanora chlarotera & & $\mathrm{x}$ & & & & & & & $\mathrm{X}$ & & & & $\mathrm{X}$ & & & & & $\mathrm{C}$ & & & \\
\hline Lecanora conizaeoides f. conizaeoides & & & & & & & & & & & $\mathrm{x}$ & & & & & & & $\mathrm{R}$ & & & \\
\hline Lecanora expallens & & $\mathrm{x}$ & & $\mathrm{x}$ & $\mathrm{x}$ & & & & & & $\mathrm{X}$ & & & & & & & $\mathrm{F}$ & & & \\
\hline Lecanora muralis & & & & & & & & & & & & & & $\mathrm{x}$ & & & $\mathrm{x}$ & $\mathrm{O}$ & & & \\
\hline Lecanora pulicaris & & & & & & & & & & & & & $\mathrm{x}$ & & & & & $\mathrm{R}$ & & & \\
\hline Lecidella elaeochroma f. elaeochroma & $\mathrm{x}$ & $\mathrm{x}$ & & & $\mathrm{x}$ & & & & $x$ & & & $\mathrm{x}$ & $\mathrm{x}$ & & & & & $\mathrm{C}$ & & & \\
\hline Lecidella scabra & & & & & & & & & & & & & & $\mathrm{x}$ & & & & $\mathrm{R}$ & & & \\
\hline Lecidella stigmatea & & & & & & & & & & & & & & $\mathrm{x}$ & & & & $\mathrm{F}$ & & & \\
\hline Lepraria finkii & & & & & & & & & & $\mathrm{X}$ & & & & $\mathrm{x}$ & & $\mathrm{X}$ & & $\mathrm{F}$ & & & \\
\hline Lepraria incana s. str. & & $\mathrm{x}$ & $\mathrm{x}$ & $\mathrm{x}$ & $\mathrm{x}$ & $\mathrm{X}$ & $\mathrm{x}$ & $\mathrm{X}$ & & & $\mathrm{x}$ & & & $\mathrm{X}$ & & & & $\mathrm{C}$ & & & \\
\hline Lepraria rigidula & & & & & & & & & $\mathrm{x}$ & & & & & & & & & $\mathrm{R}$ & $\mathrm{x}$ & $\mathrm{x}$ & \\
\hline Leptogium gelatinosum & & & & & & & & & & & & & & $\mathrm{X}$ & & & & $\mathrm{R}$ & $\mathrm{x}$ & $\mathrm{x}$ & \\
\hline Melanelixia glabratula & $x$ & & & $\mathrm{x}$ & $x$ & & & & $x$ & & $\mathrm{x}$ & & & & & & & $\mathrm{C}$ & & & \\
\hline Melanelixia subaurifera & & & & & & & & & & & $\mathrm{x}$ & & & & & & & $\mathrm{R}$ & & & \\
\hline Opegrapha ochrocheila & & & & & & & & & & $\mathrm{x}$ & & & & & & & & $\mathrm{R}$ & $x$ & $x$ & \\
\hline Parmelia saxatilis s. lat. & $\mathrm{x}$ & & & & & & & & & & & & & & & & & $\mathrm{R}$ & & & \\
\hline Parmelia sulcata s. lat. & $\mathrm{x}$ & $\mathrm{x}$ & & $\mathrm{x}$ & $x$ & & & $\mathrm{x}$ & $x$ & & $\mathrm{x}$ & & $x$ & & & & & $\mathrm{C}$ & & & \\
\hline Parmotrema perlatum & $\mathrm{X}$ & & & & & & & & & & & & $x$ & & & & & $\mathrm{R}$ & & & \\
\hline Pertusaria leioplaca & & & & & & & & & $\mathrm{x}$ & & & & & & & & & $\mathrm{R}$ & & & \\
\hline Phaeophyscia orbicularis & & & & & & & & & & & & & & $\mathrm{X}$ & & & & $\mathrm{R}$ & & & \\
\hline Phlyctis argena & & $x$ & & & & & & & & & & & & & & & & $\mathrm{R}$ & $\mathrm{X}$ & $\mathrm{X}$ & \\
\hline Physcia caesia & & & & & & & & & & & & & & $\mathrm{x}$ & & & & $\mathrm{R}$ & & & \\
\hline Physcia tenella & & & & & & & & $x$ & $\mathrm{x}$ & & $\mathrm{x}$ & & & & & & & $\mathrm{O}$ & & & \\
\hline Platismatia glauca & $\mathrm{x}$ & & & & & & & & & & & & & & & & & $\mathrm{R}$ & & & \\
\hline Porpidia crustulata & & & & & & & & & & & & & & $\mathrm{x}$ & & & & $\mathrm{R}$ & & & \\
\hline Porpidia soredizodes & & & & & & & & & & & & & & $\mathrm{x}$ & & & & $\mathrm{R}$ & & & \\
\hline Protoblastenia rupestris & & & & & & & & & & & & & & & $x$ & & & $\mathrm{R}$ & & & \\
\hline Pyrrhospora quernea & & & & & & & & & $\mathrm{X}$ & & & & & & & & & $\mathrm{R}$ & $\mathrm{x}$ & $\mathrm{x}$ & \\
\hline Ramalina farinacea & $\mathrm{x}$ & & & & & & & & & & & & & & & & & $\mathrm{R}$ & & & \\
\hline Ramalina fastigiata & & & & & & & & & $\mathrm{X}$ & & & & & & & & & $\mathrm{O}$ & $x$ & $x$ & \\
\hline Rhizocarpon reductum & & & & & & & & & & & & & & $\mathrm{x}$ & & & & $\mathrm{R}$ & & & \\
\hline Scoliciosporum umbrinum & & & & & & & & & & & & & & $\mathrm{x}$ & & & & $\mathrm{R}$ & $x$ & & \\
\hline Trapelia coarctata & & & & & & & & & & & & & & $\mathrm{x}$ & & & & $\mathrm{O}$ & & & \\
\hline Trapelia placodioides & & & & & & & & & & & & & & $\mathrm{x}$ & & & & $\mathrm{O}$ & & & \\
\hline Usnea subfloridana & $\mathrm{x}$ & & & & & & & & $\mathrm{x}$ & & & & & & & & & $\mathrm{O}$ & & & \\
\hline Verrucaria dolosa & & & & & & & & & & & & & & $x$ & & & & $\mathrm{R}$ & $x$ & $x$ & $x$ \\
\hline Verrucaria elaeina & & & & & & & & & & & & & & & & & & $\mathrm{R}$ & $x$ & $x$ & \\
\hline Verrucaria muralis & & & & & & & & & & & & & & $x$ & & $\mathrm{x}$ & & $\mathrm{R}$ & & & \\
\hline Verrucaria praetermissa & & & & & & & & & & & & & & $x$ & & & & $\mathrm{O}$ & $\mathrm{x}$ & $x$ & \\
\hline Verrucaria viridula & & & & & & & & & & & & & & $\mathrm{x}$ & & & & $\mathrm{R}$ & & & \\
\hline Xanthoria polycarpa & & & & & & & & & $\mathrm{x}$ & & & & & & & & & $\mathrm{O}$ & & & \\
\hline
\end{tabular}




\section{Substrates}

Bark

Bark is the substrate that supports the greatest lichen diversity in GBG, with 37 taxa ( $60 \%$ of the total number recorded in GBG) being found. There is a marked distinction between the lichen assemblages on young and mature trees.

Those on most mature trees are sparse, show low species diversity per tree (up to five species per tree), and are dominated by crustose species. The commonest lichen, and the only one present on some trees, is the bluish grey, sterile Lepraria incana s. str. (Fig. 1A), which is the main representative of the pollution-resistant lichen association (community sub-type) Leprarietum incanae (James et al., 1977). Some mature trees, including London planes (Platanus $\times$ acerifolia) between the Main Lawn and Great Western Road, have impoverished traces of the Pseudevernietum furfuraceae association (James et al., 1977) represented by the foliose species Parmelia sulcata s. lat., which is generally badly damaged (possibly by gastropod molluscs), and very small Hypogymnia physodes. As the oldest tree in GBG, the weeping ash (Fraxinus excelsior Pendula), planted in the original Glasgow Botanic Garden at Sandyford in 1818 and moved to its current site in 1841 (Curtis, 2006), is of particular interest. However, its trunk, heavily shaded in summer, has a very sparse scattering of lichens, which can be assigned to the Lecanoretum subfuscae association (see below) and is limited to a few colonies of the crustose Lecanora chlarotera, L. expallens and Lepraria incana (Fig. 1B). Other mature trees of note are the two large Oregon maples (Acer macrophyllum) at the east edge of the Arboretum, which carry an interesting assemblage consisting of two species not previously recorded in Glasgow - Lepraria rigidula and Opegrapha ochrocheila - and Anisomeridium polypori, previously found in Glasgow only in Linn and Pollok Parks.

By way of contrast, young trees tend to support welldeveloped examples of two associations - the Lecanoretum subfuscae and Pseudevernietum furfuraceae. The former is regarded as a pioneer community of young trees (James et al., 1977) and comprises crustose species, particularly Lecanora chlarotera, Lecidella elaeochroma f. elaeochroma and Arthonia radiata, which on some trunks form a continuous mosaic (Fig. 1C,D). With time this community grades into the Pseudevernietum furfuraceae, which is dominated by foliose and fruticose species and is particularly luxuriant on the trunks of some alders (Alnus glutinosa) in the Arboretum (Fig. 1E,F), with Hypogymnia physodes, H. tubulosa, Parmelia sulcata s. lat. and Melanelixia glabratula being prominent components. This community can show a relatively high diversity in GBG (up to 15 species per tree) and on one alder included the pollution-sensitive species Flavoparmelia caperata and Parmotrema perlatum.

\section{Lignum}

Seven species (11\% of total) were recorded on decorticated wood. Some weathered wooden benches have been colonised by $L$. chlarotera and L. elaeochroma f. elaeochroma, components of the Lecanoretum subfuscae association (Fig. 1G,H). Small specimens of Cladonia chlorophaea s. lat., $P$. sulcata s. lat. and $P$. perlatum are also present. The Ha'penny Bridge is the only location where Lecanora pulicaris was found.

\section{Stone}

There is a range of different stone substrates in GBG on which were found 24 species (39\% of total). Lichens on dressed stone, such as that used for the low boundary walls (Fig. 1I) and the Curator's House, and the red sandstone piers of Kirklee Bridge (Fig. 1J), show a lower diversity (nine species) than those on the various types of undressed/natural stone (16 species). Regarding the latter, the rocks of various sizes used as edging around the pond and in the Herb Garden have been colonised by an inconspicuous but species-rich $(n=11)$ assemblage of mainly crustose species. A more conspicuous community, visually dominated by foliose species, is present on the large alkaline dolerite boulders that have been placed at the edge of the River Kelvin near the Viewpoint in the Arboretum, apparently to protect the river bank (Fig. 1K,L). A combination of factors explains the composition of this assemblage, including the presence of moss (which provides a microhabitat for the jelly lichen Leptogium gelatinosum), periodic submersion of the boulders (Verrucaria praetermissa), and nutrient enrichment by perching birds and/or the basic nature of the substrate (Caloplaca citrina s. lat., Lecanora muralis, Phaeophyscia orbicularis, Physcia caesia).

\section{Concrete and mortar}

The combination of species growing on the Jimmy Logan memorial in the Rose Garden, i.e. Caloplaca citrina s. lat., Clauzadea monticola and Protoblastenia rupestris, is typical for man-made calcareous substrates in city locations. C. citrina s. lat. is also present on the mortar of brick and stone walls in GBG.

\section{Brick}

Although no lichens were found on old bricks, such as those in the walls of the "Long Pit" behind the Main Glasshouse, Lepraria finkii and Verrucaria elaeina occur on the bricks of a relatively new retaining wall near Garrioch Bridge.

\footnotetext{
Asphalt

Lecanora muralis grows as dispersed patches on the asphalt path in the Arboretum near the Kirklee Road entrance (Fig. 1M). It is sometimes called the "chewing gum lichen" because of its resemblance (at a distance) to that all-too-common contaminant of city pavements, and is one of several lichens that can thrive in such mechanically challenging habitats.
}

Table 1. Summary of the results of a survey of the lichens of Glasgow Botanic Gardens, Scotland, 2018-20. C, common; F, frequent; $\mathrm{O}$, occasional; $\mathrm{R}$, rare. These abundance descriptors are defined in the text. 


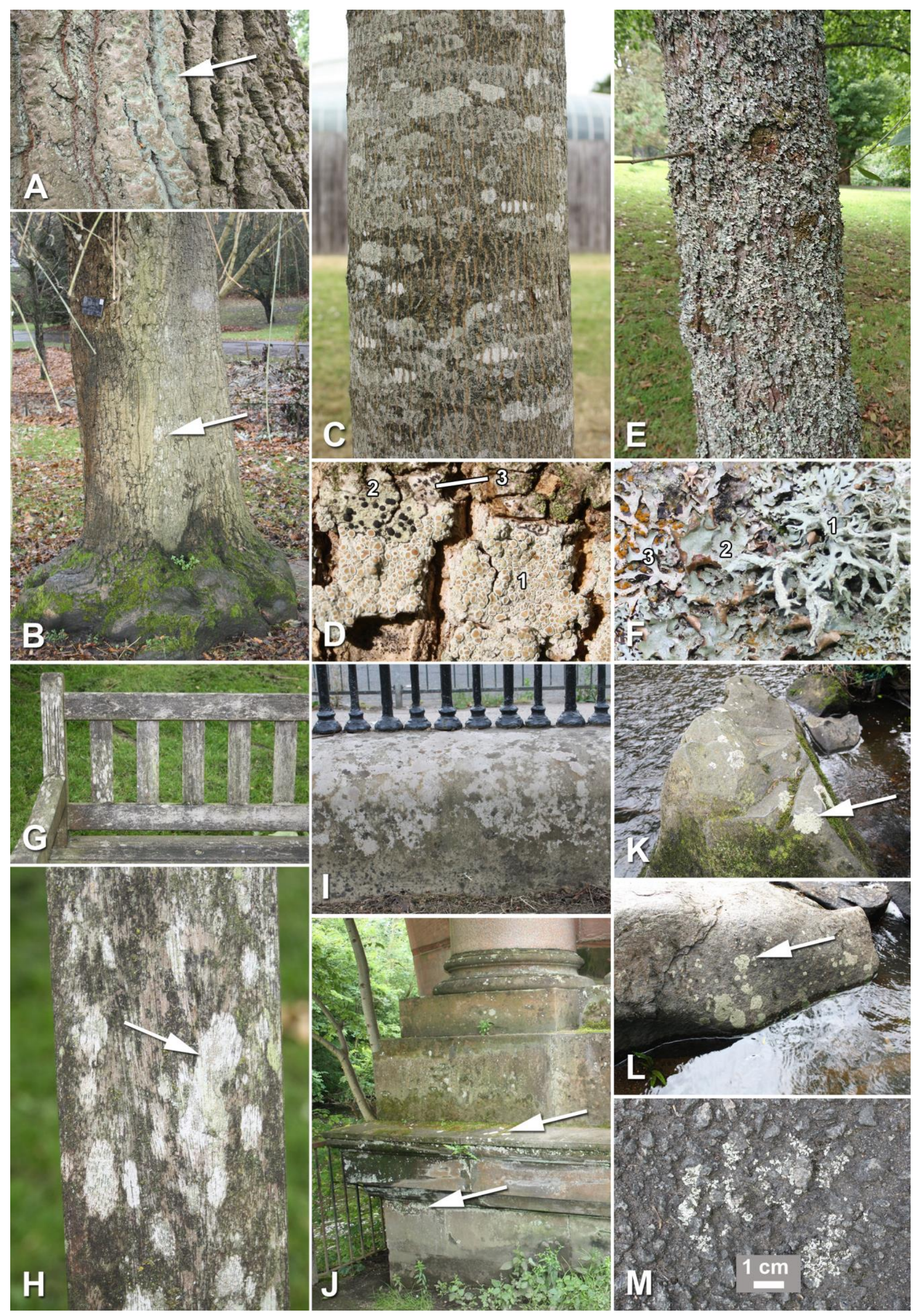




\section{Lichen taxa recorded in 2018-2020}

The statement of abundance for each taxon given below and in Table 1 is based only on how often it was found in GBG and provides no information on its wider status. Lichens described as "rare" were observed in only small quantity at one or two places in GBG; those described as "occasional" occur as larger colonies at one or two places, or as only small colonies in several places; those described as "frequent" are widespread but not anywhere in large quantity; and "common" species are widespread and present in large quantity in at least some locations (adapted from James \& Powell, 2010).

Anisomeridium polypori. Rare. In bark crevices of Oregon maples in Arboretum.

Arthonia radiata. Frequent. On bark of mainly young trees.

Baeomyces rufus. Rare. On sandstone rock near pond. Caloplaca chlorina. Rare. On boulder at edge of Kelvin near Viewpoint, Arboretum. New to Glasgow. Probably under-recorded throughout the U.K., according to Smith et al. (2009).

Caloplaca citrina $\mathrm{s}$. lat. Occasional. Very small colonies on Jimmy Logan memorial, wall of Conservatory, and mortar. British material referred to as "C. citrina" is likely to consist of one of several other species. It is not certain that $C$. citrina s. str. occurs in the U.K. (Powell \& Vondrák, 2012).

Candelariella vitellina f. vitellina. Rare. On dressed stone of Queen Margaret Drive boundary wall.

Candelariella xanthostigmoides. Frequent. Very small colonies on bark of mature and younger trees, and on lignum of wooden bench. U.K. records of this species have been previously misidentified as $C$. reflexa, which has yet to be reported correctly from Britain (Coppins $e t$ al., 2019; B.J. Coppins, pers. comm.).

Catillaria nigroclavata. Rare. On bark of small ash in Arboretum near Kirklee Road gate. New to VC77. However, probably common throughout the U.K. and spreading, but mistaken for other common species such as Amandinea punctata (Dobson, 2018).

Cladonia chlorophaea s. lat. Rare. At base of alder trunk in Arboretum and on wooded bench. C. chlorophaea s. lat. includes chemotypes that are sometimes given species status (Smith et al., 2009).

Cladonia coniocraea. Occasional. On bark, sometimes with moss, and amongst moss on rock in Herb Garden.
Cladonia macilenta. Rare. On bark of Norway maple (Acer platanoides) near Kirklee Gate.

Clauzadea monticola. Rare. On concrete of Jimmy Logan memorial.

Evernia prunastri. Occasional. On bark of alders in Arboretum.

Flavoparmelia caperata. Occasional. On bark of alders in Arboretum.

Fuscidea lightfootii. Occasional. On bark of London plane near Great Western Road and alders in Arboretum. Graphis elegans. Rare. On bark of alder in Arboretum. Hypogymnia physodes. Frequent. On bark of London plane near Great Western Road and alders in Arboretum. Hypogymnia tubulosa. Occasional. On bark of alder in Arboretum.

Lecania cyrtella. Rare. On bark of young rowan (Sorbus aucuparia) in Herb Garden. New to Glasgow.

Lecanora campestris subsp. campestris. Occasional. On sandstone rock near pond and sandstone wall of Curator's House.

Lecanora carpinea. Rare. On bark of alder in Arboretum.

Lecanora chlarotera. Common. On bark of young and mature trees including weeping ash transplanted from Sandyford Botanic Garden; also on lignum of wooden benches.

Lecanora conizaeoides f. conizaeoides. Rare. On bark of pine (Pinus sp.) in Arboretum.

Lecanora expallens. Frequent. On bark of mature trees including weeping ash transplanted from Sandyford Botanic Garden, and on younger trees, e.g. black pine (Pinus nigra) and birch (Betula utilis) in Arboretum; some extensive patches on London planes beside Main Lawn.

Lecanora muralis. Occasional. On sandstone rock near pond, boulders at edge of Kelvin at Viewpoint, and asphalt path in Arboretum.

Lecanora pulicaris. Rare. On lignum of Ha'penny Bridge. As this species is closely similar to L. chlarotera in external appearance, it may be present elsewhere in GBG and have been overlooked.

Lecidella elaeochroma f. elaeochroma. Common. On bark of young and mature trees, and on lignum of wooden benches.

Lecidella scabra. Rare. On dressed stone wall at Viewpoint, Arboretum.

Lecidella stigmatea. Frequent. On dressed stone walls and on rock near pond.

Fig. 1. Lichens of Glasgow Botanic Gardens, Scotland. (A) Lepraria incana (arrow) on lower trunk of grey poplar (Populus $\times$ canescens). 17th July 2018. (B) Trunk of weeping ash (Fraxinus excelsior Pendula) from original Glasgow Botanic Garden at Sandyford. The arrow indicates a colony of Lecanora expallens. 26th November 2019. (C) Trunk of young Norway maple (Acer platanoides) with well-developed example of the Lecanoretum subfuscae association consisting mainly of crustose lichens. 17th July 2018. (D) Some components of the Lecanoretum subfuscae association on trunk of young ash (F. excelsior), Arboretum. 1, Lecanora chlarotera; 2, Lecidella elaeochroma f. elaeochroma; 3, Arthonia radiata. 20th October 2019. (E) Trunk of alder (Alnus glutinosa) in Arboretum with well-developed example of the Pseudevernietum furfuraceae association consisting mainly of foliose and fruticose lichens. 31st July 2018. (F) Some components of the Pseudevernietum furfuraceae association on trunk of alder, Arboretum. 1, Evernia prunastri; 2, Platismatia glauca; 3, Parmelia sulcata s. lat. 20th October 2019. (G,H) Park bench near Kirklee Gate. This has been colonised by crustose lichens dominated by L. chlarotera (arrow). 30th July 2019. (I) Boundary wall next to Queen Margaret Drive. The prominent whitish lichen is Trapelia coarctata. 17th July 2018. (J) Pier of Kirklee Bridge, Arboretum. Trapelia placodioides is growing on a horizontal ledge (upper arrow) and Lepraria finkii on vertical surfaces (lower arrow). 8th July 2020. (K) Boulder in River Kelvin at Viewpoint, Arboretum. The arrow indicates Lecanora muralis. Leptogium gelatinosum grows amongst the moss on the lower part of the boulder. 30th July 2019. (L) Another boulder in River Kelvin at Viewpoint, Arboretum, with colonies of Verrucaria praetermissa (arrow). 8th July 2020. (M) Lecanora muralis on asphalt path, Arboretum. 8th July 2020. (Photos: I.C. Wilkie) 
Lepraria finkii. Frequent. On bark of Oregon maple in Arboretum, dressed sandstone (Kirklee Bridge pier and wall near Kirklee Gate), mossy rock in Herb Garden, and brick wall beside pathway north of Garrioch Bridge. Lepraria incana s. str. Common. On shaded tree trunks; some extensive patches but restricted to cracks in bark of some trees (e.g. birches in Arboretum); shaded crevices in sandstone outcrop in Arboretum.

Lepraria rigidula. Rare. On bark of Norway maple in Arboretum. New to Glasgow.

Leptogium gelatinosum. Rare. Amongst moss on boulder at edge of Kelvin near Viewpoint, Arboretum. New to Glasgow.

Melanelixia glabratula. Common. On bark of mainly young trees; notably abundant on a Bristol whitebeam (Sorbus bristoliensis) in Arboretum.

Melanelixia subaurifera. Rare. On bark of black pine in Arboretum.

Opegrapha ochrocheila. Rare. On bark of Oregon maple in Arboretum. New to Glasgow.

Parmelia saxatilis s. lat. Rare. On bark of alder in Arboretum. This is one of a group of dye-yielding Parmelia spp. known as "crotal" in Gaelic. P. saxatilis s. lat. comprises a complex of cryptic species that can be reliably distinguished by only molecular methods (Corsie et al., 2019).

Parmelia sulcata s. lat. Common. On bark of mainly young but also (in smaller quantity) some mature trees. This is another of the "crotal" lichens. Like P. saxatilis, $P$. sulcata s. lat. consists of cryptic species that cannot be distinguished in the absence of molecular information (Molina et al., 2011).

Parmotrema perlatum. Rare. On bark of alder in Arboretum and wooden bench.

Pertusaria leioplaca. Rare. On bark of young Norway maple behind Kibble Palace. The BLS Database has no Glasgow records of P. leioplaca. However, the author found it on the trunk of a sweet chestnut (Castanea sativa) in Pollok Park in 2012.

Phaeophyscia orbicularis. Rare. On boulders at edge of Kelvin near Viewpoint.

Phlyctis argena. Rare. On mossy trunk of ash in Arboretum. New to Glasgow.

Physcia caesia. Rare. On boulders at edge of Kelvin near Viewpoint.

Physcia tenella. Occasional. On bark of London plane near Great Western Road, young Norway maple behind Kibble Palace, and black pine in Arboretum.

Platismatia glauca. Rare. On bark of alder in Arboretum.

Porpidia crustulata. Rare. On rock in Herb Garden. Porpidia soredizodes. Rare. On dressed stone of Queen Margaret Drive boundary wall. Although the BLS Database has no NS56 records of P. soredizodes, the author found it on dressed sandstone in Port Dundas in 1988.

Protoblastenia rupestris. Rare. On concrete of Jimmy Logan memorial.

Pyrrhospora quernea. Rare. On bark of Norway maple near Kirklee Gate. New to Glasgow.

Ramalina farinacea. Rare. On bark of alder in Arboretum.
Ramalina fastigiata. Occasional. On bark of young Norway maples beside Kelvin Walkway and behind Kibble Palace. Very sensitive to air pollution (Smith et al., 2009). New to Glasgow.

Rhizocarpon reductum. Rare. On sandstone rock near pond.

Scoliciosporum umbrinum. Rare. On sandstone rock near pond.

Trapelia coarctata. Occasional. On dressed stone of Queen Margaret Drive boundary wall and undressed sandstone rock near pond and in Herb Garden.

Trapelia placodioides. Occasional. On dressed red sandstone of Kirklee Bridge pier. All colonies unusual in lacking soralia (discrete areas of the upper surface that produce vegetative propagules consisting of clusters of algal cells and fungal hyphae).

Usnea subfloridana. Occasional. On bark of young Norway maple beside Kelvin Walkway and alder in Arboretum.

Verrucaria dolosa. Rare. On boulder at edge of Kelvin near Viewpoint. New to VC77.

Verrucaria elaeina. Rare. On brick, wall beside pathway north of Garrioch Bridge. New to Glasgow.

Verrucaria muralis. Rare. On sandstone rock in Herb Garden.

Verrucaria praetermissa. Occasional. On boulder at edge of Kelvin near Viewpoint. New to Glasgow.

Verrucaria viridula. Rare. On dressed stone of Queen Margaret Drive boundary wall.

Xanthoria polycarpa. Occasional. On bark of young Norway maples beside Kelvin Walkway and behind Kibble Palace.

\section{DISCUSSION}

\section{Previous records}

Previous records of lichens in GBG are summarised in Table 2. Six previously recorded species were not found in 2018-20. Of these, Candelariella aurella and Myriolecis dispersa were present in 1986 on a low boundary wall at the Queen Margaret Drive entrance. These species are common in Glasgow and are likely to still occur in GBG but to have been overlooked in 2018-20. The other four species - Cladonia digitata, C. fimbriata, Lecanora intricata and L. polytropa - were found in 1986 on the low wall of the old Herb garden, which was located at that time near the Kibble Palace (Hancock, 1998; Curtis, 2006), and on rocks edging the old pond. These lichens were casualties of the subsequent removal of the Herb Garden to another site and the destruction and re-establishment of the pond during the renovation of the Kibble Palace around 2004 (Sutcliffe, 2019). All four species are common in Glasgow and may persist elsewhere in GBG.

No conclusions can be drawn from the apparently impressive addition of 54 lichen taxa to the previous GBG list of 14 species, due to the brevity of the author's visits in 1975 and 1986 and the fact that the Arboretum, which accounts for much of the present lichen diversity of GBG (see below), was not opened to the public in its present form until 1977 and was not visited by the author in 1986. There has, however, been one definite change 


\begin{tabular}{|c|c|c|c|}
\hline \multirow[b]{2}{*}{ Taxon name } & \multicolumn{2}{|c|}{ Substrate } & \multirow{2}{*}{ 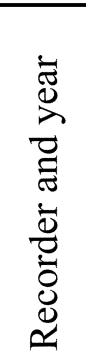 } \\
\hline & $\begin{array}{l}\frac{y}{\bar{E}} \\
\text { ص }\end{array}$ & $\begin{array}{l}\stackrel{\mathscr{0}}{\tilde{0}} \\
\stackrel{\mathscr{n}}{\sim}\end{array}$ & \\
\hline Candelariella aurella & & $x$ & 3 \\
\hline Cladonia coniocraea & & $x$ & 3 \\
\hline Cladonia digitata & & $x$ & 2,3 \\
\hline Cladonia fimbriata & & $x$ & 3 \\
\hline Hypogymnia physodes & $x$ & & 2,3 \\
\hline Lecanora conizaeoides & $x$ & & $1,2,3$ \\
\hline Lecanora intricata & & $x$ & 3 \\
\hline Lecanora polytropa & & $x$ & 3 \\
\hline Lecidella stigmatea & & $x$ & 3 \\
\hline Lepraria incana s. lat. & $x$ & & 3 \\
\hline Myriolecis dispersa & & $\mathrm{x}$ & 3 \\
\hline Parmelia saxatilis s. lat. & $x$ & & 3 \\
\hline Platismatia glauca & $x$ & & 3 \\
\hline Porpidia crustulata & & $x$ & 3 \\
\hline
\end{tabular}

Table 2. Previous records of lichens from Glasgow Botanic Gardens, Scotland. Species not found in 2018-20 are highlighted in bold text. Lepraria incana is designated "sensu lato" because records of this species made before 1992 are unreliable due to subsequent taxonomic advances (Smith et al., 2009). 1, G.P. O'Hare (1974); 2, I.C. Wilkie (1975, pers. obs.); 3, I.C. Wilkie (1986, pers. obs.).

in the lichens of GBG. The author recorded that the corticolous (growing on bark) crust Lecanora conizaeoides was "very common" in 1975 and "abundant" in 1986. In 2018-20 L. conizaeoides was "rare", occurring as small, easily overlooked, sterile colonies on the bark of a pine in the Arboretum. L. conizaeoides has declined dramatically across the U.K. over the past 20-30 years. It requires very acidic substrates, which were plentiful from the 19th to the late 20th centuries as a result of high levels of atmospheric sulphur dioxide caused by the burning of coal. Massara et al. (2009) concluded that its retreat was linked to an increase in bark $\mathrm{pH}$ due to a combination of the reduction in sulphur dioxide emissions that followed the Clean Air Act of 1956 and rising emissions of ammonia originating from the catalytic convertors of road vehicles. Although once very common throughout the city, L. conizaeoides had not been recorded in Glasgow since 1991 (pers. obs.). It may have survived on a pine trunk in GBG because of the naturally low $\mathrm{pH}$ of pine bark (Marmor \& Randlane, 2007; Fojcik et al., 2017).

Whilst a quantitative approach was not taken in either the 2018-20 survey or the brief 1975 and 1986 surveys, it is the author's subjective impression that there has been little recovery of the corticolous lichen communities on mature trees over the past 30 years. As in 1975 and 1986, non-crustose species - particularly Hypogymnia physodes, Parmelia sulcata s. lat. and Physcia tenella - are still sparse and present as very small or damaged individuals. In addition, other moderately pollution-tolerant non-crustose species that might have been expected to have gained a foothold, such as Evernia prunastri and Platismatia glauca, were not found on mature trees. This may be a consequence of present atmospheric levels of nitrogen compounds (discussed below) or of the "toxic legacy" of decades of air pollution that rendered old bark resistant to lichen colonisation (Powell et al., 2017). In view of the presence on young trees of E. prunastri, P. glauca and other non-crustose species, the latter is more likely.

\section{8-20 records}

In the 2018-20 survey 62 lichen taxa were found in GBG, bringing the total number recorded since 1974 to 68. The Glasgow parks whose lichens have been most thoroughly investigated are Linn and Pollok Parks, both located at the southern edge of the city and both visited independently by at least two professional lichenologists during the past 50 years. The BLS Database lists 47 lichen taxa for Linn Park and 80 for Pollok Park, suggesting that GBG has a surprisingly rich lichen diversity for a relatively small park in a quite central, urbanised location, though up-to-date information from other Glasgow parks would be needed to confirm this.

Most of the lichen species found in GBG $(60 \%$ of the total number) grow on bark, there being a notable difference between the generally sparse, species-poor, mainly crustose communities associated with mature trees and the sometimes luxuriant and more diverse assemblages present on young trees. The richer lichen cover on young trees partly explains the disproportionate contribution of the Arboretum to lichen diversity in GBG. Although the Arboretum occupies only around $20 \%$ of the total area of GBG, 23 (37\%) of the GBG lichen taxa were found only in it. Furthermore, of the 15 corticolous species present only on young trees, ten of these $(67 \%)$ were restricted to the Arboretum. This is a reflection of both the preponderance of young trees in the Arboretum, which was not developed in its present form until the 1970s (Curtis, 2006), and the wide variety of trees that have been planted. The alders of the Arboretum make a particularly significant contribution to lichen diversity in GBG: 17 species were found on their trunks, seven of which were not recorded elsewhere in the Gardens (Table 1).

The same distinction between the lichens on mature and young trees is seen in other Glasgow parks (pers. obs.). One possible explanation is that the lichen communities currently present on young trees colonised their bark when they were at the nursery stage in a less polluted, possibly rural location and were imported into GBG with the trees. This, however, does not apply to the relatively luxuriant Pseudevernietum furfuraceae association on some of the alders in the Arboretum, since these trees were grown on site from seed received 
in 1993 (A. Sinclair, pers. comm.). The assemblage has therefore developed in situ and, since it includes pollution-sensitive lichens such as Ramalina fastigiata (previously unrecorded in Glasgow), Parmotrema perlatum and Flavoparmelia caperata, it may be an indication of improving air quality.

The main factor restricting lichen growth in cities is air pollution. As a result of the reduction in sulphur dioxide emissions over the past 50 years, nitrogen compounds are now the main pollutants affecting lichens in Europe (Munzi et al., 2014). The influence of these on lichens is complicated, with different chemical forms of different pollutants having varied effects, including direct toxicity. For example, some nitrogen compounds cause nutrient enrichment of substrates, which encourages the growth of nitrophytes - lichens that tolerate or thrive on such substrates, while at the same time, by increasing the $\mathrm{pH}$ of substrates (mentioned above), they inhibit acidophytes - lichens that tolerate or thrive in acidic conditions (James \& Powell, 2010). An important nitrogenous pollutant is nitrogen dioxide $\left(\mathrm{NO}_{2}\right)$ derived from vehicle exhaust emissions. Air quality monitoring in Queen Margaret Drive, which is adjacent to the eastern boundary of GBG, shows that the mean level of $\mathrm{NO}_{2}$ in 2014-2018 was $31.3 \mu \mathrm{g} \mathrm{m}^{-3}$ (with no apparent trend over that period) (Reid, 2019). Whilst there is evidence that this concentration of $\mathrm{NO}_{2}$ affects lichen communities, for example by increasing the proportion of nitrophytes (Gadson et al., 2010), it is also known that $\mathrm{NO}_{2}$ levels quickly drop off away from roads (ca. 70\% within 20-30 m: Davies et al., 2007). There are indications that lichen diversity and development in GBG might be influenced by nitrogen deposition: (1) the presence of the nitrophyte Candelariella xanthostigmoides (albeit in very small quantity) on many mature and young trees, and on lignum; (2) the rarity of Parmelia saxatilis s. lat., which is usually a prominent member of the Pseudevernietum furfuraceae association (James et al., 1977) but is also sensitive to nitrogen pollution (van Herk, 1999; Will-Wolf et al., 2015); and (3) the luxuriance on some young trees, and significant presence on some mature trees, of Parmelia sulcata s. lat., which, though not considered to be a nitrophyte, appears to be quite tolerant of nitrogen pollution (Davies et al., 2007; Smith et al., 2009). If nitrogenous pollutants are inhibiting lichen colonisation and growth in GBG and other Glasgow parks, then the ongoing switch from hydrocarbonfuelled to electrical vehicles bodes well for the future of these organisms throughout the city.

The finding of lichens new to Glasgow and new to VC77 is likely to be less a consequence of GBG possessing features extraordinarily conducive to lichen diversity, and more an indication that the city's lichens have been generally under-investigated. It is hoped that the present contribution will stimulate renewed interest in this relatively neglected aspect of Glasgow's natural history.

\section{ACKNOWLEDGEMENTS}

I am very grateful to Dr B.J. Coppins for verifying identifications and providing BLS Database records,
Dr N.D.L. Clark for geological information, R.K.S. Gray and A. Sinclair for information on GBG trees, K.J. Watson for alerting me to the presence of Leptogium gelatinosum, and a reviewer for suggesting improvements to the text.

\section{REFERENCES}

Baniya, C.B., Solhøy, T., Gauslaa, Y. \& Palmer, M.W. (2010). The elevation gradient of lichen species richness in Nepal. The Lichenologist 42, 83-96. https://doi.org/10.1017/S0024282909008627

Coppins, B.J., Seaward, M.R.D. \& Simkin, J. (2019). British Isles list of lichens and lichenicolous fungi. September 2019 update to list. British Lichen Society Bulletin 125, 66-72.

Corsie, E.I., Harrold, P. \& Yahr, R. (2019). No combination of morphological, ecological or chemical characters can reliably diagnose species in the Parmelia saxatilis aggregate in Scotland. The Lichenologist 51, 107-121. https://doi.org/10.1017/S0024282919000069

Curtis, E.W. (2006). The Story of Glasgow's Botanic Gardens. Argyll Publishing, Glendaruel.

Davies, L., Bates, J.W., Bell, J.N.B., James, P.W. \& Purvis, O.W. (2007). Diversity and sensitivity of epiphytes to oxides of nitrogen in London. Environmental Pollution 146, 299-310. https://doi.org/10.1016/j.envpol.2006.03.023

Dobson, F.S. (2018). Lichens. An Illustrated Guide to the British and Irish Species. (7th edition). The Richmond Publishing Company, Slough.

Elliot, G.F.S. (1901). Lichens. In: Elliot, G.F.S., Laurie, M. \& Murdoch, J.B. (Editors). Fauna, Flora and Geology of the Clyde Area, pp. 50-60. British Association for the Advancement of Science, Glasgow.

Fojcik, B., Chruścińska, M. \& Nadgórska-Socha, A. (2017). Epiphytic habitats in an urban environment; contamination by heavy metals and sulphur in the barks of different tree species. Polish Journal of Natural Sciences 32, 283-295.

Gadson, S.R., Dagley, J.R., Wolseley, P.A. \& Power, S.A. (2010). Relationships between lichen community composition and concentrations of $\mathrm{NO}_{2}$ and $\mathrm{NH}_{3}$. Environmental Pollution 158, 2553-2560. https://doi.org/10.1016/j.envpol.2010.05.019

Hancock, E.G. (1998). Introduction. On the wildside: the natural history of the Glasgow Botanic Gardens. The Glasgow Naturalist 23(3), 42-43.

James, P.W., Hawksworth, D.L. \& Rose, F. (1977). Lichen communities in the British Isles: a preliminary conspectus. In: Seaward, M.R.D. (Editor). Lichen Ecology, pp. 295-413. Academic Press, London.

James, P.W. \& Powell, M. (2010). The lichens of Sutton Park, Warwickshire. British Lichen Society Bulletin 107, 2-17.

Lutzoni, F. \& Miadlikowska, J. (2009). Lichens. Current Biology 19, R502-R503. https://doi.org/10.1016/j.cub.2009.04.034

Marmor, L. \& Randlane, T. (2007). Effects of road traffic on bark $\mathrm{pH}$ and epiphytic lichens in Tallinn. Folia Cryptogamica Estonica 43, 23-37. 
Massara, A.C., Bates, J.W. \& Bell, J.N.B. (2009). Exploring causes of the decline of the lichen Lecanora conizaeoides in Britain: effects of experimental $\mathrm{N}$ and $\mathrm{S}$ applications. The Lichenologist 41, 673-681. https://doi.org/10.1017/S0024282909990119

Molina, M.C., Divakar, P.K., Millanes, A.M., Sánchez, E., Del-Prado, R., Hawksworth, D.L. \& Crespo, A. (2011). Parmelia sulcata (Ascomycota: Parmeliaceae), a sympatric monophyletic species complex. The Lichenologist 43, 585-601. https://doi.org/10.1017/S0024282911000521

Munzi, S., Correia, O., Silva, P., Lopes, N., Freitas, C., Branquinho, C. \& Pinho, P. (2014). Lichens as ecological indicators in urban areas: beyond the effects of pollutants. Journal of Applied Ecology 51, 1750-1757. https://doi.org/10.1111/1365-2664.12304

O'Hare, G.P. (1974). Air Pollution and Lichens in the Western Central Lowlands of Scotland. Ph.D. thesis, University of Glasgow.

Powell, M., Beale, J. \& Shipway, P. (2017). Lichens in Greenwich Park. British Lichen Society Bulletin 121, 45-52.

Powell, M. \& Vondrák, J. (2012). Yellow sorediate crusts called "Caloplaca citrina" in England. British Lichen Society Bulletin 110, 20-24.

Reid, K. (2019). 2019 Air Quality Annual Progress Report (APR) for Glasgow City Council. Glasgow City Council.

Smith, C.W., Aptroot, A., Coppins, B.J., Fletcher, A., Gilbert, O.L., James, P.W. \& Wolseley, P.A. (2009). The Lichens of Great Britain and Ireland. (2nd edition). The British Lichen Society, London.

Stewart, E.J.A. (1925). Some Glasgow lichens. Annals of the Andersonian Naturalists' Society 4, 76-83.

Sutcliffe, R. (2019). Non-avian vertebrates in Glasgow Botanic Gardens. The Glasgow Naturalist 27(1), 6970. https://doi.org/10.37208/tgn27113

van Herk, C.M. (1999). Mapping of ammonia pollution with epiphytic lichens in the Netherlands. The Lichenologist 31, 9-20. https://doi.org/10.1006/lich.1998.0138

Will-Wolf, S., Jovan, S., Neitlich, P., Peck, J.E. \& Rosentreter, R. (2015). Lichen-based indices to quantify responses to climate and air pollution across northeastern U.S.A. The Bryologist 118, 59-82. https://doi.org/10.1639/0007-2745-118.1.059 